\title{
Portuguese anti-money laundering policy: a game theory approach
}

\author{
Shital Jayantilal \\ Universidade Portucalense \\ Portucalense Institute for Legal Research - IJP, \\ Research on Economics, Management and Information Technologies - REMIT \\ Portugal \\ Email: shital@upt.pt, \\ + 351934081258 \\ Corresponding Author \\ Sílvia Ferreira Jorge \\ Universidade de Aveiro \\ Departamento de Economia, Gestão e Engenharia Industrial / GOVCOPP \\ Portugal \\ Email: sjorge@ua.pt
}

\section{Ana Ferreira}

Portugal

Email: anasferreira.portugal@gmail.com 


\title{
Portuguese anti-money laundering policy: a game theory approach
}

\begin{abstract}
The fight against money laundering has taken centre stage in the global arena. The European Union (EU), in line with various international organizations, plays an active role in the fight against this crime and promotes anti money laundering directions to its member states.
\end{abstract}

The statistics regarding Portugal (a member of the EU since 1986) indicate that it lags behind most of the EU members in terms of reporting of suspicions of money laundering. This paper adopts a game theory approach to study the efficiency of the combat against money laundering in Portugal, both with regards to the financial and the non financial sector of the economy. Additionally, the paper studies the impact of the increase of sanctions, as recommended by the $4^{\text {th }}$ Directive $2015 / 849$ of the European Parliament and of the Council of $20^{\text {th }}$ May of 2015, on that combat.

The results show that the low probability of the institutions being caught (and fined) for not complying with their reporting duties, coupled with the low conviction rates for money laundering crimes, justifies the reduced number of suspicious transactions reported. The findings highlight that an increase of sanctions, on both financial and non financial institutions, would tend to augment the efficiency of the combat against money laundering in Portugal.

Keywords: Banking Sector, Non financial Institutions, Money Laundering, Game Theory

JEL: G21, G23, C78, K42 


\section{INTRODUCTION}

In the last decades of the $20^{\text {th }}$ century, money laundering has become a problem of global dimension driven by a series of worldwide tendencies such as: the progressive liberalization of capital movements and international trade; the surge of new and complex financial instruments; the creation and development of new technologies and telecommunications and the existence of tax havens (Vaithilingam, Nair \& Thiyagarajan, 2015). Money laundering is seen as the dark side of the globalization process (Brandão, 2002).

Although the exact dimension of the problem is difficult to quantify, given its very nature, various estimates indicate that it has a significant impact. This criminal phenomenon affects all countries and Portugal is no exception.

Portugal is a small country situated at the western tip of Europe. The establishment of a democratic regime in 1974 was followed by a decolonization process and slowly Portugal traded its Atlantic orientation for Europe, integrating the European Union (EU) in 1986. After joining the EU, Portugal began to register high levels of growth but structural deficiencies persist (Becker, Philipson \& Soares, 2003). More recently, the Portuguese economy, like so many others worldwide, was shaken by the global financial crisis of 2010. In order to cope, Portugal's prime minister at the time, José Socrates, requested financial assistance to the IMF and the EU and in 2011, he oversaw the negotiations which ensured the 78 billion euro bail-out. Subsequently, José Socrates lost the general election but, in November of 2014, he was back in the headlines when he was arrested on suspicion of money laundering and other criminal activities. ${ }^{1}$

Another scandal implicates Ricardo Salgado, head of one of the oldest and most influential families in Portuguese banking, who was also detained on money laundering suspicions, in 2014. Ricardo Salgado was in charge of Espírito Santo Group, which, among various business interests worldwide, held one of the largest and oldest banks in Portugal - Banco Espírito Santo (BES) - which was later split in two banks: Novo Banco, which kept its healthy operations, and a "bad bank" to keep its toxic assets.

\footnotetext{
${ }^{1}$ Retrieved from http://uk.reuters.com/article/uk-portugal-corruption-socrates-idUKKCN0J606D20141122/.
} 
Shareholders and investors in the family companies and BES have lost many billion euros, making this one of the biggest corporate collapses in the history of Europe. ${ }^{2}$

Earlier, in 2008, another Portuguese banker -José Oliveira e Costa - president of Banco Português dos Negócios (BPN), was also arrested, on suspicion of money laundering among other crimes. The bank was later nationalized, although it represented a marginal share of the banking sector. The justification given for the bail-out was to prevent any contamination to the financial system. Yet many speculated that more than 7billion euros of tax payers money was used to save the bank where many politicians (including the president Cavaco Silva) had interests. ${ }^{3}$

It has not only been banks and bankers and politicians who have been in the lime light in Portugal, due to money laundering suspicions. A complex investigation, code named 'Matryoshkas' uncovered ties to the Russian mafia and to off-shore shell companies, and led to the detention, in mid 2016, of Russian businessman, Alexander Tolstikov, owner of a third-tier Portuguese football team, União Desportiva de Leiria, detained on money laundering suspicions. ${ }^{4}$

These are just a handful of cases which have been brought to the attention of the general public given the notoriety of the key individuals involved, and have highlighted the importance of combating money laundering in Portugal.

The objective of this paper is two-fold. Firstly, to study the efficiency of the money laundering combat Portugal, both with regards to the financial and the non financial sector of the economy. Secondly, to analyze the impact on that efficiency of the application of the $4^{\text {th }}$ Directive, Directive 2015/849 of the European Parliament and of the Council of $20^{\text {th }}$ May of 2015, in particular, the reinforcement of sanctions to the institutions who do not comply with the anti-money laundering measures. In order to do so we model two games which describe the institutional process under money laundering combat, first on the financial institutions, focusing on banks, and then on the non financial institutions. Our paper contributes to the analysis of the efficiency of anti-

\footnotetext{
${ }^{2}$ Retrieved from http://www.reuters.com/article/us-portugal-bes-salgado-idUSKBNOFT0XS20140724/.

${ }^{3}$ Retrieved from http://uk.reuters.com/article/portugal-bpn-idUKLDE76K0KP20110721/.

${ }^{4}$ Retrieved from http://edition.cnn.com/2016/05/04/europe/portugal-russian-mafia-allegations/.
} 
money laundering policies, using an economic modeling methodology, game theory model, which predicts the rational behavior of the institutional players in this process. The Nash equilibrium results show a higher propensity to report, in equilibrium, for the banks, when compared to the non financial institutions. Our findings illustrate that the raise in sanctions will increase the propensity of all obliged institutions to report any suspicion of money laundering. Additionally, our results emphasize that an effective inspection and supervision process will also augment the propensity of all obliged institutions to report such suspicions.

This paper begins with the presentation of the money laundering combat in the Portuguese context, which is then followed by the presentation of the model and discussion of the results. The paper finalizes by, reflecting on the implications, and limitations, of our findings in terms of the efficiency of the anti-money laundering policy in Portugal, and suggests future avenues of research.

\section{ANTI-MONEY LAUNDERING IN PORTUGAL}

Although there is not a consensus on exactly what is the definition of money laundering, it is generally accepted that it is a process through which criminals conceal the real origin of the revenue/property, obtained through illicit means, endowing it with some legitimate appearance to make it legally reusable (Masciandaro, 1999). This process encompasses three stages: (1) Placement: the illegally derived funds are placed into the financial system, usually through a financial institution; (2) Layering: that revenue/property is used in multiple transactions to conceal its origin; (3) Integration: the 'washed' revenue is reintroduced in the legitimate economy. Figure 1 illustrates these phases. 
Figure 1: The phases of money laundering

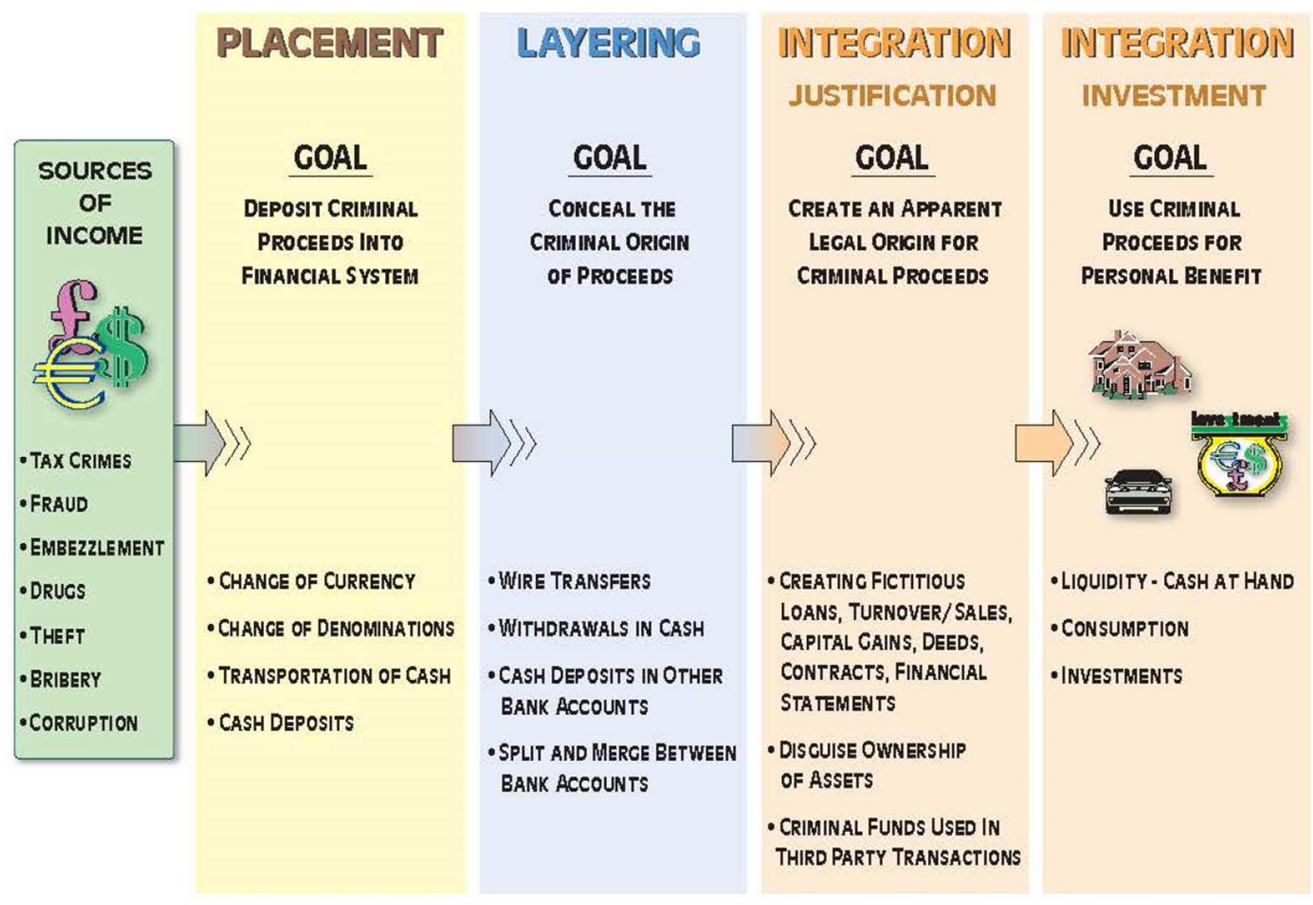

Source: Organization for Economic Co-operation and Development - OECD (2009, p.11)

The Placement stage is the most critical for the money launderer as it is the closest to the origin and also where it is easiest for the revenue flows to be detected. Any action of the authorities in this stage has a higher probability of establishing the connection with the crime which precedes the money laundering, and, therefore, catching the criminal (Buchanan, 2004). As the money laundering advances to the further stages of the process, the harder it is for the authorities to detect and hold the criminals responsible (Braguês, 2009).

Money laundering dictates significant costs to the economy, asserts political pressure and erodes the confidence on the international financial systems (Ardizzi, Petraglia, Piacenza, Schneider \& Turati, 2014). Additionally it distorts competition among firms and incites criminal behavior, leading to social unrest and launches ethical concerns (Dion, 2015). For Morgado e Vegar (2007) money laundering is the heart of organized crime. The threat that money laundering poses and the negative consequences it has on the economy and on society at large makes combating it vital (Simser, 2013). 
The end of the 80s marked the establishment of the first international judicial measures to combat money laundering. The United Nations Vienna Convention, signed in 1988, had the express objective to fight against the introduction into the economic and financial system, of the huge profits resulting from illicit trafficking in narcotic drugs. This was a historic milestone and marked the beginning of a joint international effort to condemn and combat money laundering (Godinho, 2001).

Various conventions, resolutions and international declarations followed, as did the establishment of various international organisms driven to fight money laundering. Amongst theses, we highlight the G7 meeting, of 1989, in Paris, which established the Financial Action Task Force (FATF) a group which has played a key role in this combat. This inter-governmental body aims to set standards and promote effective implementations of all necessary measures in that combat. The FATF provides recommendations which are intended as being a comprehensive plan of action to combat money laundering, and other threats to the integrity of the international financial system (FATF, 2013).

The EU has followed these international efforts and, since 1991, has published four Directives on money laundering binding its Member States to the intended results yet giving them the freedom to choose and implement the necessary means to attain those objectives. The $4^{\text {th }}$ Directive, Directive (EU) 2015/849 of the European Parliament and of the Council of $20^{\text {th }}$ May of 2015 , focuses on prevention of the use of the financial system for the purposes of money laundering or terrorist financing.

This Directive aims to follow the international standards of combat in particular the revised FATF Recommendations of 2012 and even goes beyond those to ensure greater safety and effectiveness to the fight against crime. One of the key items of this Directive is the reinforcement of the sanctions and fines applied to institutions who do not comply with their obligations in this combat. The Directive broadens the range of sanctions and measures, both economic and non-economic, which member states can additionally apply but highlights the need to take into account the differences between the various institutions given their size, characteristics and the nature of the business (ex. financial vs. non financial institutions). 
The Portuguese legislation began to pay attention to money laundering in 1993 and, like most countries, started by exclusively criminalizing money laundering related to illicit trafficking in narcotic drugs. Since then, following the international frameworks, various national legislative instruments have been approved, broadening both the scope and the duties of the entities subject to help preventing this crime, as well as reinforcing international cooperation.

Currently, in Portugal there is a legal framework for combating money laundering and also a separate criminal offence in the penal code.

The Article 368-A of the Portuguese Penal Code criminalizes money laundering, states which activities in relation to proceeds of crime are forbidden and lists the relevant crimes covered, known as predicate offences to money laundering. Money laundering is a complex crime and its nature can only be fully understood when coupled with the crime that precedes it (Leite, 2013).

The Lei (Law) n. $25 / 2008$, of $5^{\text {th }}$ July, established all the preventive and repressive measures in the combat of money laundering and the financing of terrorism. The aim is to avoid the crime from being committed and/or to detect it as soon as possible. In order to do so, the legislation calls upon all the economic players to their part, from individuals to firms, including not only public but also privately help enterprises. It divided all these institutions in financial and non financial. The first group includes, among others, banks and other financial institutions while the non financial sector is a very heterogeneous compromising, for instance, lawyers, accountants to car dealers and casinos.

Each of those institutions, according to the law, is obliged to perform certain duties. The key general duties are: (i) identification (to have 'know your customer' procedures in place); (ii) due diligence; refusal (to undertake any action if lacking identification and precious due diligence); (iii) conservation (keep all records for at least 7 years); (iv) examination (examine all transactions to determine if might be money laundering); (v) reporting (immediately report to the Portuguese Financial Intelligence Unit (FIU) and 
the Procurador-Geral da República (PGR) ${ }^{5}$, of any suspicious transactions); (vi) abstention (abstain from executing any action if is a suspicious transaction); (vii) collaboration (obliged to collaborate with all the competent legal bodies); (viii) secrecy (required to maintain the whole process secret and not inform the clients or other parties of any ongoing suspicion or investigation); (ix) control (put in place adequate internal control mechanisms to address their obligations); and $(\mathrm{x})$ training (provide adequate information and training to staff in relevant positions to combat money laundering).

From all of these, the duty to report both to the FIU and the PGR is the corner stone of the entire system of prevention. In fact, without this information only sporadically could the relevant authorities have the information to combat money laundering (Canas, 2010). In reality, as Canas (2004) points out, an efficient combat to money laundering is highly dependent on the efforts of private institutions. In fact, these firms are required to apply their own time and resources to this fight and, at times, risk losing clients and business in the process.

All the institutions are subject to inspection and supervision of the fulfillment of their duties in the combat of money laundering, the Bank of Portugal plays this role for the banking sector, whereas for the non financial institutions, the entity responsible for preventive supervision depends on the nature of the institution (for example, by the Chamber of Solicitors for the solicitors, or the Institute of Construction and Real Estate for firms operating in that sector). These entities can apply sanctions, to the institutions under their supervision, when they come across situations of non compliance with the anti money laundering duties.

Figure 2 shows the number of suspicious transactions reports (STR) made both by financial and non financial institutions in the EU, in 2008. In all member states the number of STR made by non financial institutions is residual and, in some cases, nonexistent. Comparing between all EU member states, Latvia leads in terms of the total number of STR and it is quite evident that Portugal lags behind.

\footnotetext{
${ }^{5}$ This is the Prosecutor-General of the Portuguese Republic.
} 
Figure 2: Number of suspicious transactions reports in the EU in 2008

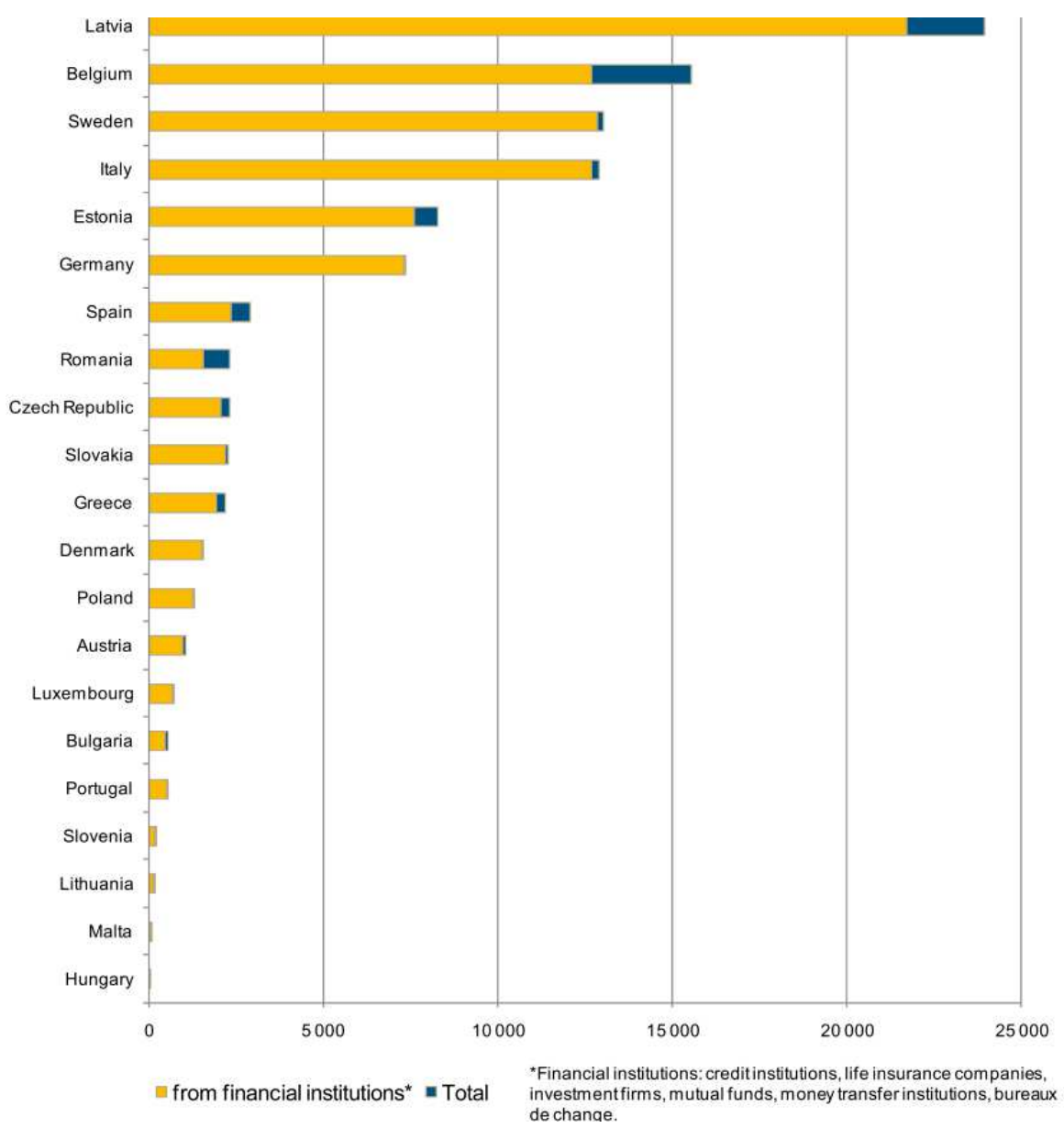

Source: European Commission (2010, p.26)

In light of the Portuguese reality, once STRs are received by the FIU and the PGR, these are assessed. This is the intelligence stage, and only those STR where suspicious are confirmed are passed on to the investigation stage which is conducted by the Public Prosecution Office (PPO) and the Orgão de Polícia Criminal (OPC) ${ }^{6}$. Depending on the results of the investigation the PPO decides whether or not to pursue the case and if so will take it to court. Figure 3 illustrates the entire process.

\footnotetext{
${ }^{6}$ This is the Criminal Police Unit which aids the PPO in the investigation.
} 
Figure 3: The stages and respective responsible agencies in the combat of money laundering in Portugal
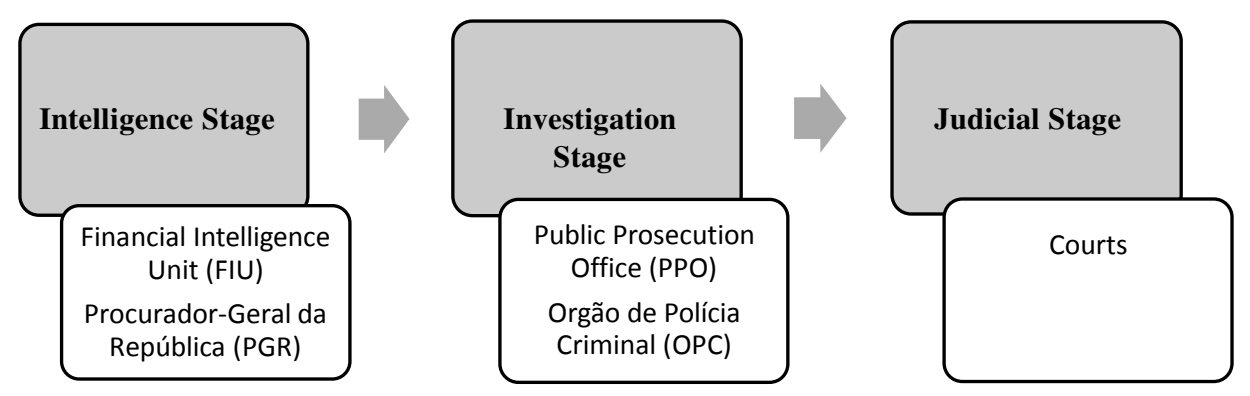

The statistics provided by the FIU show that there is a decrease in the total number of $\mathrm{STR}^{7}$, however banks have registered a steady increase in these reports from 2008 to 2013 as is illustrated in Table $1 .^{8}$

Table 1: Number of STR the FIU received, from 2008 to 2013

\begin{tabular}{|c|c|c|c|c|c|c|}
\hline STR reported by: & 2008 & 2009 & 2010 & 2011 & 2012 & 2013 \\
\hline Financial Institutions & 723 & 829 & 2.178 & 3.884 & 2.568 & 2.319 \\
\hline Banks & 671 & 753 & 1.061 & 1.083 & 1.444 & 1.771 \\
\hline Non Financial Instituions & 15 & 13 & 46 & 244 & 391 & 368 \\
\hline Registery Offices & & & 39 & 230 & 354 & 333 \\
\hline Sellers of high value goods & 8 & 3 & 2 & 7 & 22 & 22 \\
\hline Lawyers and Solicitors & 0 & 0 & 0 & 0 & 0 & 0 \\
\hline Accountants, external auditors and consultants & 0 & 0 & 0 & 0 & 0 & 1 \\
\hline Supervision and Inspection entities & 21.289 & 12.951 & 6.246 & 4.001 & 4.225 & 3.690 \\
\hline Inspection and Supervision of gambling activities & 21.142 & 12.852 & 6.142 & 3.912 & 4.144 & 3.608 \\
\hline Others & 706 & 1.406 & 2.153 & 1.599 & 1.277 & 1.177 \\
\hline Total & 22.733 & 15.199 & 10.623 & 9.728 & 8.461 & 7.554 \\
\hline
\end{tabular}

The reporting by non financial institutions has a marginal role. In fact, it is evident that these institutions have a very low number of reports and some of these (such as lawyers, solicitors, accounts, auditors and consultants) have not reported any suspicious activities in those 6 years (with the exception of a single STR in 2013). In this regard, Portugal is not the exemption, but rather confirms the pattern of the majority of EU states. Various authors (ex: Kelkar \& Rao, 2013) have pointed out that those institutions (comparatively to banks and other financial institutions) find it much harder to inform

\footnotetext{
7 All the reports received are those sent to the FIU.

${ }^{8}$ This decrease is essentially due to the fall in the number of STR reported by the supervision and inspection entity of gambling activities (Serviços de Inspecção de Jogos do Turismo de Portugal).
} 
the authorities as this translates in higher economic (i.e. loss of clients and business) and non economic (i.e. reputation) costs.

Given the total number of STR which the FIU receives, only those where it confirms the suspicious nature of the transactions are followed through to the investigation stage, in charge of the PPO and the OPC. The cases which are directed to the investigation stage represent a very low percentage of the total STR, as Table 2 indicates.

Table 2: Number of STR received, enquiries opened and suspicions confirmed by the FIU between 2008 and 2013 in Portugal

\begin{tabular}{|l|r|r|r|r|r|r|}
\cline { 2 - 7 } \multicolumn{1}{c|}{} & \multicolumn{1}{c|}{$\mathbf{2 0 0 8}$} & $\mathbf{2 0 0 9}$ & $\mathbf{2 0 1 0}$ & $\mathbf{2 0 1 1}$ & \multicolumn{1}{c|}{$\mathbf{2 0 1 2}$} & $\mathbf{2 0 1 3}$ \\
\hline N.. STR received & 22.733 & 15.199 & 10.623 & 9.728 & 8.461 & 7.554 \\
\hline N..-enquiries opened & 568 & 634 & 703 & 684 & 745 & 954 \\
\hline N..- de STR with suspicions confirmed & 300 & 188 & 240 & 721 & 512 & 446 \\
\hline
\end{tabular}

Source: FIU

The PPO and the OPC then investigate those STR and decide which to take to the judicial stage. From 2007-2012 only an infinitesimal of those cases have led to convictions for money laundering, as shown by Table $3 .^{9}$

Table 3: Number of convictions for money laundering by the Court of First Instance, from 2007 to 2012

\begin{tabular}{|c|r|r|r|r|r|r|}
\cline { 2 - 7 } \multicolumn{1}{c|}{} & \multicolumn{1}{c|}{$\mathbf{2 0 0 7}$} & \multicolumn{1}{c|}{$\mathbf{2 0 0 8}$} & $\mathbf{2 0 0 9}$ & $\mathbf{2 0 1 0}$ & $\mathbf{2 0 1 1}$ & $\mathbf{2 0 1 2}$ \\
\hline №. Convictions & 5 & 9 & 12 & 13 & 6 & 17 \\
\hline
\end{tabular}

Source: Direcção Geral de Politia de Justiça (Portuguese Directorate-General for Justice Policy)

The statistical data available, specifically the extremely low number of convictions for money laundering, the reduced number of suspicious confirmed (in comparison to those communicated) coupled with the decrease in STR, raises the question regarding the efficiency of the combat measures of money laundering in Portugal.

The most recent changes to Lei n. ${ }^{\circ} 25 / 2008$, implemented at the end of 2014, aggravates the sanctions applied to those who do not comply with the obligation to report suspicious transactions. For example, if a bank is caught not having given information of a suspicious transaction then it can be subject to a fine of up to 5 million euros which

\footnotetext{
${ }^{9}$ The accounting of the convicted people relates to the most serious offence for which they were accused.
} 
can be elevated to $10 \%$ of the total annual turnover. This increment in terms of sanctions is also suggested by the $4^{\text {th }}$ Directive of the EU, which refers an increase in the fines but also recommends augmenting other non monetary costs (ex. reputation costs). In the particular case when the obliged institution concerned is a bank, then that breach in its obligations should be identified by a public statement.

In this paper we will use game theory to contribute to a better understanding of the Portuguese reality, as reflected by the statistics, and also study the impact that the increase of sanctions for not reporting suspicious transactions can have on the efficiency of the fight against money laundering.

\section{THE GAME THEORY MODEL}

To analyze the impact of the new anti-money laundering policy measures we adopt a game theoretic approach. Game theory studies decision making, by rational players, when facing strategic behavior. The strategic interdependence is the essence of game theory. In the beginning of the XX century, game theory was established as a field in its own right. Several papers demonstrated diverse possibilities of application of game theory in economics (Borel (1921), Morgenstern and von Neuman (1929, 1944)). In 1950, John Nash developed an equilibrium concept for noncooperative games, known as the Nash equilibrium. Since then, game theory has been applied to various areas in economics and has expanded to political science, sociology, psychology, conflict management, design of auctions for resource allocation, negotiation theory, problems of war and evolutionary biology. The Swedish Nobel committee awarded Nobel Memorial Prizes in Economic Sciences to game theory improvements: John Nash, John Harsanyi and Reinhard Selten (1994) and Vernon L. Smith and Daniel Kahneman (2002).

A game is formal description of a strategic situation. A game is defined by its players (agents who make the decisions), their information set (the possible actions available to them) and their preferences and payoffs (the payoff of each player is influenced by his actions but also by the actions of the other players). Non-cooperative game theory analyzes strategic decision making by rational players. The reporting decision is 
essentially a non-cooperative strategic decision, involving the banks/non-financial institutions and also the FIU and the PPO strategies'. We adjust the game proposed by Araújo (2009) to include the most recent recommendation of the EU Directive 2015/849 of the European Parliament and of the Council of $20^{\text {th }}$ May of 2015. We extend that game to study the impact that an increase of the sanctions applied, as recommended by that Directive, has in terms of the efficiency of combating money laundering in Portugal. Our analysis encompasses both financial and non financial institutions.

The mathematic foundations of game theory provide a rigorous and objective analysis to study the efficiency of the combat measures of money laundering. In order to study both the financial institutions - focusing on the banking (Game 1) and the non financial institutions (Game 2), we model two sequential games of perfect information. In these games the players move in sequence and are fully aware of the strategies available to each one, and observe all the moves made before making theirs. These games are expressed in extensive form, as a tree, and are defined by: (i) the players of the game; (ii) when each player has to choose a strategy; (iii) what each player can decide at each point; and (iv) the payoffs for the players resulting from each of the possible combination of strategies.

Both games have three players: the FIU; the $\mathrm{PPO}^{10}$ and, for Game 1, the bank (B); whereas for Game 2, the other player is the non financial institution (NFI). Our model presents the payoffs which reflect the order of preference of every strategic outcome for each player. The highest payoff is (3) and the lowest is (-3).

\subsection{Game 1: Banking sector}

Figure 4 illustrates Game 1 which focuses on the banking sector and resumes all the payoffs for each of the players.

\footnotetext{
${ }^{10}$ The Intelligence stage and the Investigative stage also include the PGR and the OPC, respectively, but to simplify the exposition in the model we do not directly refer to these.
} 
Figure 4: Game 1 Tree representation for the banking sector

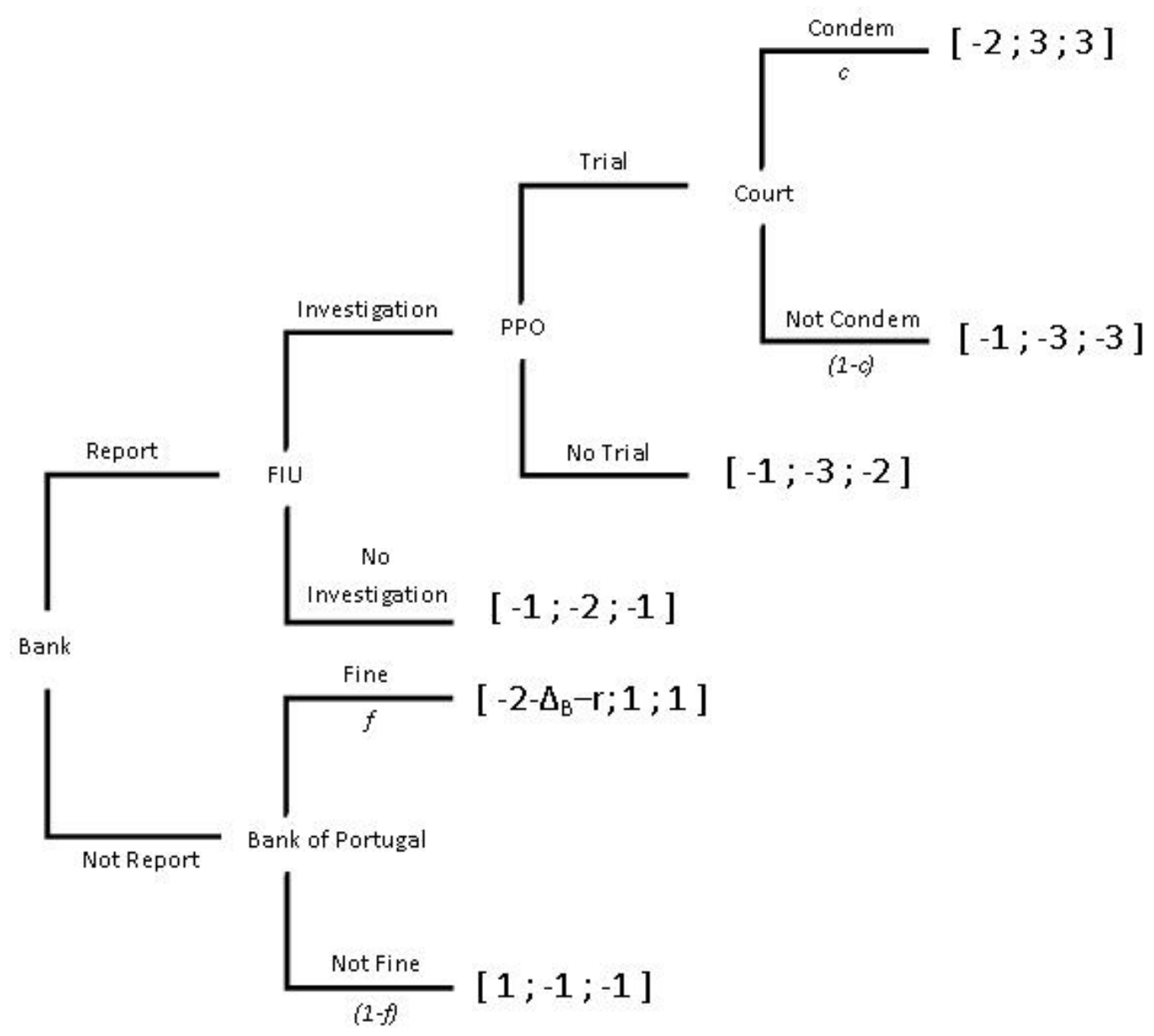

We set the payoffs for the three players, where the first number relates to the payoff of the first player (bank), the second is the payoff obtained by the FIU and finally the third number is the payoff of the PPO. For instance, when the bank reports the suspicious activity, and the FIU decides to send the report for further investigation; and the PPO decides to take the case to trial, then the bank's payoff is $(-2)$, the FIU has a payoff of (3), as does the PPO.

Taking a closer look at the game, we start at the first node which represents the first move, played by the Bank, which decides between reporting (r) or not reporting (nr) a suspicious transaction to the FIU. The Portuguese legislation requires banks to report all suspicious transactions and sanctions are applied if they do not comply. When the bank decides not to report the suspicious transaction, we model uncertainty in terms of the 
payoffs since the Bank of Portugal can, via inspection and supervision, catch that infraction and apply a fine to the bank (with probability $f$ ) or not catch it and thus not apply that fine (with probability $(1-f)$ where $0 \leq f \leq 1)$. If the Bank of Portugal recognizes that the bank did not comply then the bank's payoff will be $\left(-2-\Delta_{\mathrm{B}}-\mathrm{r}\right)$. The negative payoff is due to the fine the bank needs to pay, $\Delta_{B}$ stands for the possible increase of sanctions as proposed by the $4^{\text {th }}$ Directive $\left(\Delta_{B}>0\right)$ and $r$ stands for potential reputation damage since if the bank does not report and the Bank of Portugal catches the infraction the bank loses credibility, and its reputation. If, however, the Bank of Portugal, is unable to detect the bank's infraction then the bank's payoff is 1 because, in this case, the bank does not have to pay the fine and also saves on the costs related to the reporting activities. Therefore, the expected bank payoff if the bank does not report is: $f *\left(-2-\Delta_{\mathrm{B}}-\mathrm{r}\right)+(1-f)^{*}(1)=1-3 f-f\left(\Delta_{\mathrm{B}}-\mathrm{r}\right)$. We assume that, when the bank does not report, both FIU and PPO get a payoff of $(-1)$ when the Bank of Portugal does not apply a fine and (1) otherwise, since FIU and PPM aim to combat money laundering.

On the other hand, the bank can comply and report the suspicious transaction to the FIU, who in turn can either decide to send it to for further investigation (i) or not (ni). The payoff in either case will be $(-1)$ for the bank, reflecting the cost related to the reporting activities. If the FIU decides not to send it for further investigation, the payoff of the FIU is $(-2)$, resulting from the cost it sustained with the analysis of the STR and also the cost related to the loss of reputation it suffers for having decided to stop the process from following through to the next stage. In this particular case, the PPO has a payoff of $(-1)$ since it sees this as a lost opportunity in the fight against money laundering. If the FIU decides to send it to further investigation, the PPO has two possible strategies: to take the case to trial (t) or not (nt). When the PPO decides to take the case to court, we assume that there is a probability $(c)$ that the court will condemn the client on money laundering, whereas, with probability $(1-c)$, the court will not condemn (where $0 \leq c \leq 1$ ). ${ }^{11}$ When the court's final decision is not to condemn, both the FIU and the PPO get a payoff of $(-3)$, as in this case, there are costs they sustained

\footnotetext{
${ }^{11} \mathrm{We}$ assume when the game starts, these two probabilities, $f$ and $c$, are common knowledge for all players.
} 
with the entire process (intelligence, investigation and judicial costs) but also the cost of loss of reputation for not being able to present a solid enough case to get a conviction. Notice that this is the only case where the bank has payoff $(-2)$. This is because the bank sustains not only the cost related to the reporting activities, but also of losing its client. When the PPO does not pursue the case to the judicial stage the payoffs of the PPO are $(-2)$, due to the loss of reputation PPO suffers for having decided to stop the process but the payoffs of the FIU are (-3) since there is an extra loss due to the end of the process after the FIU decision to investigate further.

\subsection{Game 2: Non financial institutions sector}

Figure 5 shows the game tree representation of Game 2 which refers to all the non financial institution which, by the Portuguese law, are also obliged to report any suspicious transactions. In this game there are also three players: the non financial institution (NFI), the FIU and the PPO.

This game presents three main differences when compared to Game 1:

(i) If the designated responsible entity for the inspection and supervision of the NFI recognizes that the NFI did not comply then, we assume that, the payoff for NFI will be $\left(-1-\Delta_{N F}-r\right)$ (since the sanctions for these institutions are lower than those of the banks and where $\Delta_{N F}$ stands for the possible increase of sanctions as proposed by the $4^{\text {th }}$ Directive and $r$ stands for potential reputation damage).

(ii) We assume that the payoff for the NFI, when it reports its suspicions to the FIU, is of (-4). This reflects the higher costs, both of economic (such as: loss of business) and non economic (such as: administrative) nature it sustains when compared with the banks.

(iii) If the PPO goes to trial and gets a conviction, the NFI registers an even lower payoff (equal to $(-5)$ ) due to the effective loss of that particular client.

Game 2 unfolds just like the previous game and Figure 5 resumes all the payoffs for each player. 
Figure 5: Game 2 Tree representation for the Non Financial Institutions

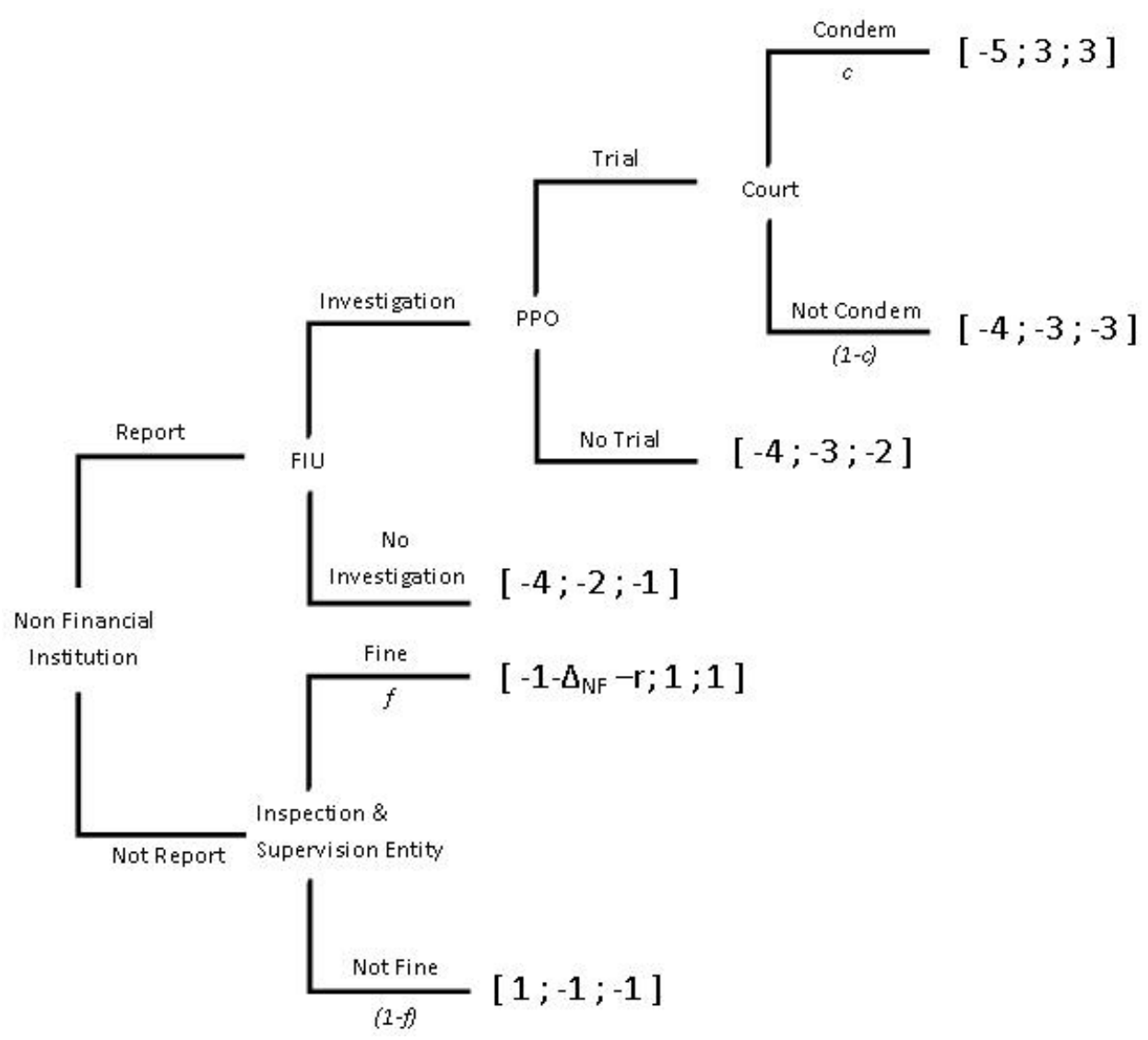

\subsection{Results and discussion}

To solve both the games, we used backward induction considering the probabilities, $f$ and $c$. For sequential games with perfect information, backward induction should be used and this technique warrants each player to look ahead and think backwards, before making his decision: starting at the terminal node and including the probabilities, $f$ and $c$, choose the best option, and then proceed to the next-to-last node, identifying the optimal action for the player, assuming he anticipates what will follow and continue this procedure, moving backwards, until arriving at the root (Kreps, 1990). Notice that institutions reporting and moreover the process reaching the judicial stage is the optimal solution for these games and thus the more efficient result. Both games present four pure subgame perfect Nash equilibria. In two of these, the bank/non financial institution 
report and in the other two, they do not. ${ }^{12}$ Figures 6 and 7 summarize these Nash equilibrium results for all the possible probabilities, $f$ and $c$.

Figure 6: Nash equilibrium results of Game 1

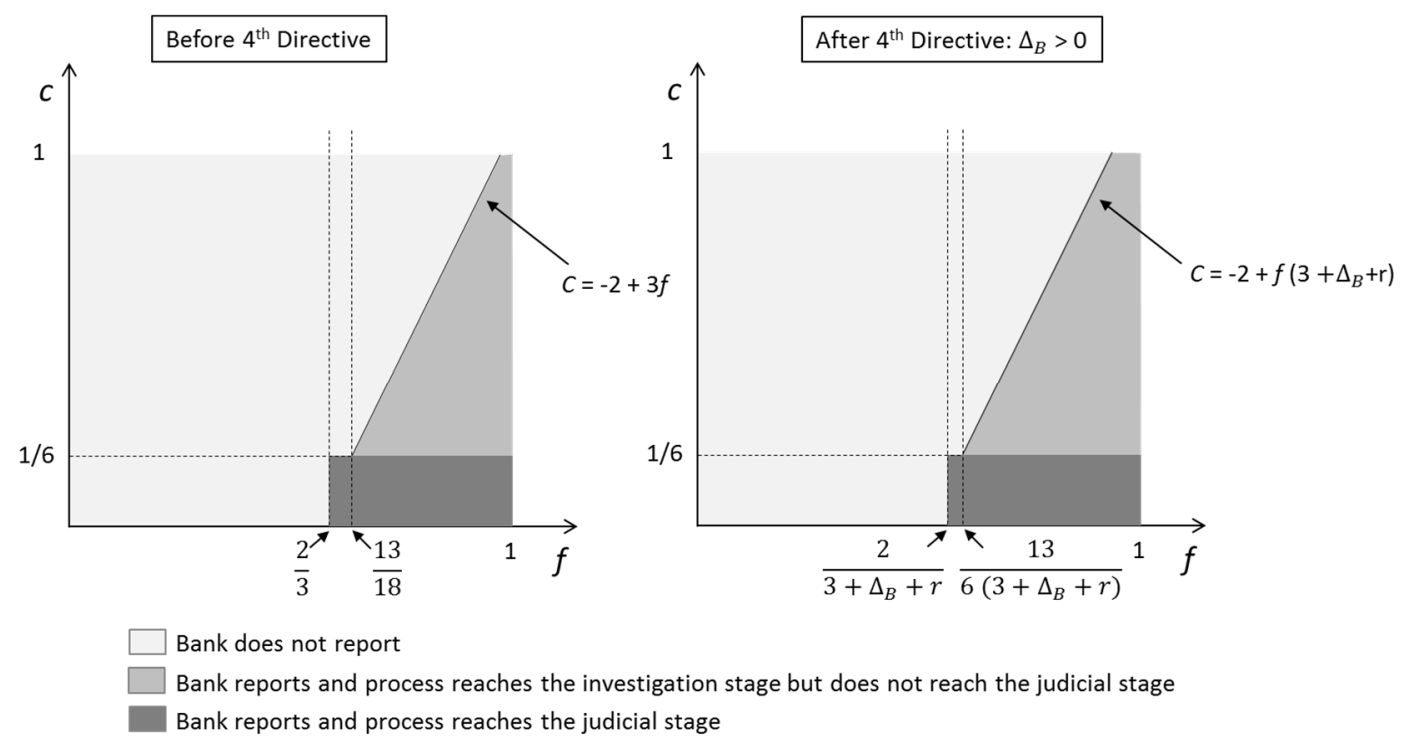

Our model indicates that when there are higher probabilities of being fined when caught not complying with the reporting duties $(f)$ and of there being a conviction $(c)$, then the bank does comply and report the suspicious transaction. However, the results show that even when $c$ is high, only for very high $f$ does the bank report. In other words, this analysis emphasizes the importance of the Bank of Portugal being more vigilant (higher probability of catching any possible not compliance) to ensure that the banks do report any suspicion of money laundering they may come across. For low probabilities, low $f$ and $c$, the equilibrium analysis shows that banks do not report. In other words, when they know there is a low probability of being caught if they do not comply and even if they do comply, there is a low probability of a conviction being secured, then they prefer not to report.

\footnotetext{
12 The Nash equilibria are: i) Bank / NFI: r; FIU: i; PPM: t; ii) Bank / NFI: r; FIU: i; PPM: nt; iii) Bank / NFI: nr; FIU: i; PPM: t; iv) Bank / NFI: nr; FIU: ni; PPM: nt.
} 
Figure 7: Nash equilibrium results of Game 2
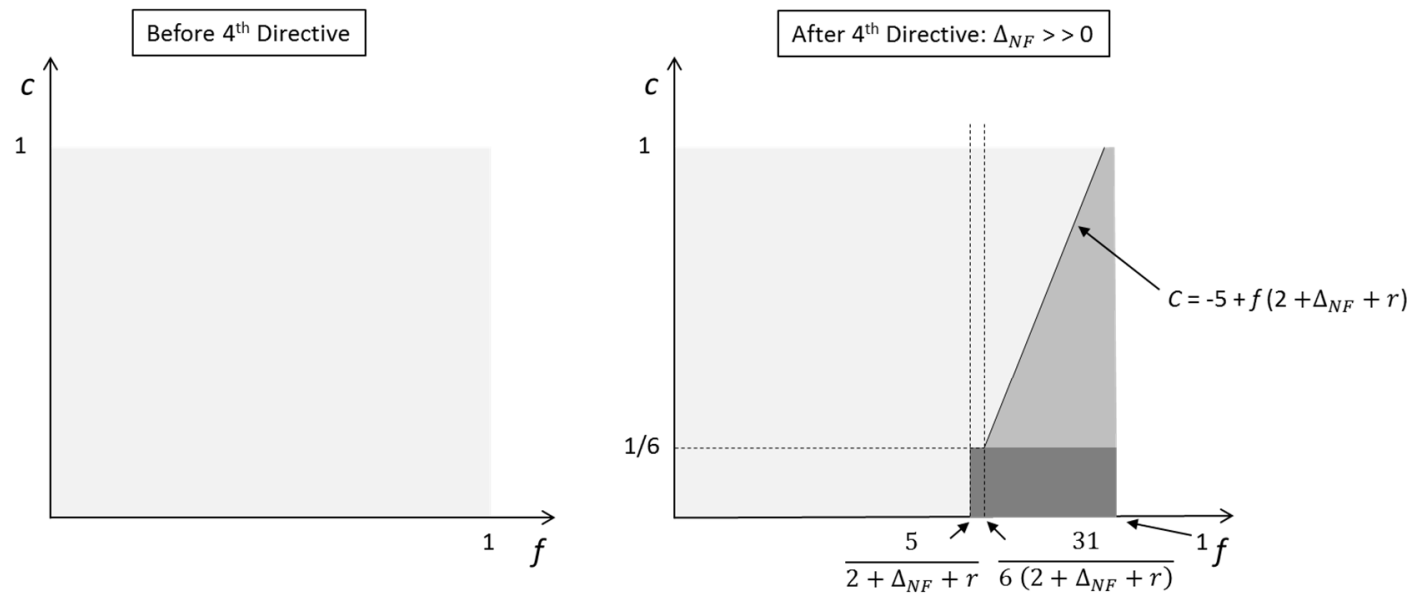

NFI does not report
NFI reports and process reaches the investigation stage but does not reach the judicial stage
NFI reports and process reaches the judicial stage

For the NFI, and focusing first on the case before the reinforcing of the sanctions as suggested by $4^{\text {th }}$ Directive, then, for all possible probabilities, $f$ and $c$, Game 2 only presents the Nash equilibrium where the NFI does not report. As $\Delta_{\mathrm{NF}}$ increases, NFI starts to report in equilibrium, for high $f$ and $c$.

The comparison between the two games clearly shows that there is a lower propensity to report for NFI. These results substantiate the Portuguese reality, where the number of STR by NFI is far lower than those of financial institutions. Additionally, it contributes to understand the rationality behind the zero STR registered in various NFI (ex. lawyers, solicitors, etc), in the past years in Portugal (see Table 1).

Our findings also show that an increase of the sanctions applied, as recommended by the recent EU Directive, raises the efficiency of combating money laundering in Portugal for the banking sector since for higher $\Delta_{\mathrm{B}}$, there is always higher propensity to 
report (illustrated in Figures 3 and 4, since all the darker shaded grey areas increase their dimension for higher $\left.\Delta_{\mathrm{B}}\right) \cdot{ }^{13}$

To enhance the propensity of NFI reporting it is necessary to significantly ${ }^{14}$ raise $\Delta_{\mathrm{NFI}}$ as illustrated in the plot of the right in Figure 7. 15

Also for both type of institutions if the potential reputation damage increases, there is always higher propensity to report and thus raises the efficiency of combating money laundering. ${ }^{16}$ In practical terms, our findings show that the authorities should employ the necessary measures to, on the one hand, promote higher probabilities of catching breaches of the institutions obliged in reporting suspicions of money laundering and, on the other, increment the probability of a condemnation. This will lead to the Nash equilibrium which is to report.

\section{CONCLUSION}

The fight against money laundering has become a global priority given the costs that it imposes both economically but also on society at large. The anti-money laundering policies and practices have been orchestrated by the key international agencies, with the cooperation of the various countries.

Portugal, a member of the EU, has put in place diverse instruments and various measures, in line with the EU Directives, to combat this crime. In light of the Portuguese anti-money policy, this combat is driven by both repressive measures and those more preventive in nature. However, the corner stone of this combat is the detection of any suspicious activities both in the financial system, and also by other institutions through which possible laundering of money could occur. That information plays a crucial role. The available statistics shows that in Portugal, (as with other

\footnotetext{
${ }^{13}$ We show that the derivative of the darker shaded grey areas in terms of $\Delta_{B}$ is always positive.

${ }^{14}$ This is reinforced in the title of the right plot in Figure 7 with the double increase sign $(>>)$.

${ }^{15}$ Notice that before the recent EU Directive, there was no Nash equilibrium where NFI reports but as $\Delta_{\mathrm{NF}}$ increases, NFI starts to report in equilibrium, for high $f$ and $c$.

${ }^{16}$ We show that the derivative of the darker shaded grey areas in terms of $r$ is also always positive.
} 
member states) the non financial institutions play a marginal role in that reporting. In fact, in Portugal, in the past years there have been some professions (such as lawyers, solicitors and auditors) which have not filed one single suspicious transactions report. On the other hand, there has been a steady rise of reporting by the banks, in the same period.

This article resorts to mathematical and solid foundations of game theory, to study the efficiency of anti-money laundering policy and extends it to predict the impact that a possible increase in sanctions, as recommended by the $4^{\text {th }}$ EU Directive, could have on that efficiency, in Portugal. The results show that low probability of a breach by an obliged institution being caught and the low probability of the money laundering crime being convicted (even when the institutions do report) justify the low number of suspicious transactions reports. The findings further demonstrate that adopting the recommendation of increasing sanctions will induce an increase in the propensity of reporting not only for banks but also for NFI, where these were very low or nonexistent.

In practical terms, and for the policy makers, our findings highlight the importance of implementing the EU Directive recommendation of increasing sanctions but also ensuring their effective implementation, through more efficient supervision and inspection. It is essential that sanctions are effective and dissuasive promoting a more efficient combat. Additionally, our findings highlight the importance of adopting measures which contribute to the increase in the probability of those caught in money laundering to be actually convicted.

This paper reinforces the usefulness of game theory in studying the efficiency of antimoney laundering policy. An opportunity for future research would be to resort to other type of games, such as those of imperfect information games. For instance, where institutions may decide to signal their anti-money laundering alignment or where policy makers can design sanctions and fines to create incentives for different types of institutions to act anti-money laundering.

Also an important extension to our model would be to include other players such as the person planning to lauder illicitly obtained funds. 
Finally, future work may consider other potential factors that might influence the decision making (following Levi (2006) the model could capture the role of information exchange between institutions and also from Harvey (2005) the model setup could study what might be regarded as deterrent for cooperation between the institutions and law enforcement agencies).

\section{REFERENCES}

Araújo, R. (2009). Assessing the efficiency of the Brazilian anti-money laundering regulation: a game theoretic approach, Revista de Economia do Mackenzie, 7 (1), pp. 30-42.

Ardizzi, G., Petraglia, C., Piacenza, M., Schneider, F. \& Turati, G. (2014). Money laundering as a crime in the financial sector: a new approach to quantitative assessment, with an application to Italy, Journal of Money, Credit and Banking, 46 (8), pp. 1555-1590.

Braguês J. (2009). O processo de branqueamento de capitais. [Working paper n. ${ }^{\circ}$ 2/2009 do Observatório de Economia e Gestão da Fraude]. Edições Húmus. Localização web: http://www.gestaodefraude.eu.

Brandão, N. (2002). Branqueamento de capitais: O sistema comunitário de prevenção. Coimbra: Coimbra Editora.

Becker, G. S., Thomas, J.P. \& Soares, R.T. (2003). The quantity and quality of life and the evolution of world inequality, American Economic Review, 95 (1), pp. 277-291.

Buchanan, B. (2004). Money laundering- a global obstacle. International Business and Finance, 18 (1), pp-115-127.

Canas, V. (2004). O crime de branqueamento: Regime de prevenção e de repressão. Coimbra: Almedina.

Canas, V. (2010). As medidas d. natureza preventiva contra o branqueamento e o financiamento do terrorismo. In Bandeira, G. \& Silva, L. N (coord.). Branqueamento de capitais e injusto penal: Análise dogmática e doutrinária comparada luso-brasileira (pp.485-554) Lisboa: Editorial Juruá.

Dion, M. (2015). Is money laundering an ethical issue?, Journal of Money Laundering 
Control, 18 (4), pp. 425-437.

Ex-BES chief Salgado named as suspect in money-laundering probe. (2014, July 24).

Retrieved from http://uk.reuters.com/article/uk-portugal-corruption-socratesidUKKCN0J606D20141122/.

FATF (2013). International Standards on combating money laundering and the financing of terrorism \& proliferation: The FATF recommendations. Paris: FATF/OECD.

Godinho, J.A.F. (2001). Do crime de branqueamento de capitais: Introdução e tipicidade. Coimbra: Almedina.

Harvey, J. (2005). An evaluation of money laundering policies. Journal of Money Laundering Control, 8(4), pp. 339-345.

Kelkar, A. \& Rao, A. (2013). Co-designing compliance to the Anti-Money Laundering Act within the small and medium enterprise sector. Journal of Financial Regulation and Compliance, 21 (1), pp. 84-101.

Kreps, D. M. (1990). Game theory and economic modeling. Oxford, Clarendon Press.

Leite, A.L. (2013). Do crime antecedente e do delito de branqueamento praticado pelo mesmo agente: regresso ao passado? In Infrações económicas e financeiras: estudos de criminologia e direito (pp. 462-477). Coimbra: Coimbra Editora.

Levi, M. \& Reuter, P. (2006). Money Laundering. Crime and Justice, 34 (1) pp. 289375

Masciandaro, D. (1999). Money laundering: the economics of regulation, European Journal of Law and Economics, 7 (3), pp. 225-240.

Morgado, M.J. \& Vegar, J. (2007). O inimigo sem rosto: Fraude e corrupção em Portugal (5. ${ }^{\mathrm{a}}$ ed). Lisboa: Publicações D. Quixote.

Organization for Economic Co-operation and Development - OECD (2009). Money Laundering Awareness Handbook for Tax Examiners and Tax Auditors. Paris: OECD.

Police: Money-laundering scheme involved Portuguese soccer club. (2011, July 21). Retrieved from http://edition.cnn.com/2016/05/04/europe/portugal-russian-mafiaallegations/. 
Portugal receives four bids for failed bank BPN. (2011, July 21). Retrieved from http://uk.reuters.com/article/portugal-bpn-idUKLDE76K0KP20110721/.

Portuguese ex-PM Socrates arrested in corruption probe. (2014, November 22). Retrieved from http://uk.reuters.com/article/uk-portugal-corruption-socratesidUKKCN0J606D20141122/.

Simser, J. (2013). Money laundering: emerging threats and trends, Journal of Money Laundering Control, 16 (1), pp. 41-54.

Vaithilingam, S., Nair, M. \& Thiyagarajan, T. (2015). Managing money laundering in a digital economy, Journal of Asia-Pacific, 16 (1), pp. 44-65.

Yeoh, P. (2014). Enhancing effectiveness of anti-money laundering laws through whistleblowing, Journal of Money Laundering Control, 17 (3), pp. 327-342. 